\title{
Strategi brand activation Perguruan Tinggi Muhammadiyah Aisyiyah di masa pandemi COVID-19
}

\author{
Erwin Rasyid ${ }^{1}$, Ade Putranto Prasetyo Wijiharto Tunggali ${ }^{2}$ \\ ${ }^{1,2}$ Universitas Aisyiyah Yogyakarta, Yogyakarta, Indonesia
}

\begin{abstract}
ABSTRAK
Sejak awal kemunculannya di Wuhan, penyebaran COVID-19 di seluruh dunia telah menyebabkan perubahan besar dalam interaksi sosial di berbagai sektor, termasuk sektor pendidikan. COVID-19 juga memiliki tingkat penyebaran yang sangat cepat dan masif dibandingkan dengan virus-virus yang pernah ada sebelumnya. Menurut analisis jaringan dari kampus Cornell menunjukkan bagaimana universitas merupakan ruang yang rentan menjadi kluster penyebaran COVID-19. Pandemi COVID-19 tidak hanya memaksa perguruan tinggi mengubah metode pembelajarannya. Berdasarkan hasil koordinasi Asosiasi Perguruan Tinggi Swasta (APTSI), sejumlah perguruan tinggi swasta di Indonesia terancam mengalami kebangkrutan akibat berkurangnya jumlah mahasiswa baru. Muhammadiyah sebagai gerakan Islam berkemajuan yang juga banyak berkontribusi di sektor pendidikan, tentu tidak terlepas dari dampak yang ditimbulkan oleh Pandemi COVID-19. Penelitian ini bertujuan untuk menganalisis bagaimana aktivitas brand activation PTMA di masa Pandemi COVID-19. Aktivitas brand activation yang menjadi strategi komunikasi pemasaran yang PTMA dalam mencapai target penerimaan jumlah mahasiswa baru. Penelitian ini merupakan jenis penelitian kualitatif deskriptif dengan menggunakan pendekatan studi kasus. Subjek dari penelitian ini adalah Perguruan Tinggi Muhammadiyah Aisyiyah yang berbasis di Daerah Istimewa Yogyakarta. Subjek PTMA tersebut terdiri dari Universitas Ahmad Dahlan, Universitas Muhammadiyah Yogyakarta, dan Universitas Aisyiyah Yogyakarta. Hasil penelitian ini menunjukkan bahwa kegiatan brand activation yang dilaksanakan PTMA di masa pandemi berbasis bantuan dan sukarelawan. Kegiatan brand activation PTMA di masa pandemi ini juga memanfaatkan media sosial atau biasa disebut sebagai strategi pada kegiatan promosi dan publikasi. Segala aktivitas brand activation tetap merujuk pada pelaksanaan caturdharma perguruan tinggi dan tetap merujuk pada kebijakan penanganan COVID-19 pimpinan pusat Muhammadiyah.
\end{abstract}

Kata-kata Kunci: Strategi; brand activation; COVID-19; perguruan tinggi; Muhammadiyah Aisyiyah

\section{Brand activation strategy for Muhammadiyah Aisyiyah college in the COVID-19 pandemic period}

\section{ABSTRACT}

Since its initial appearance in Wuhan, the spread of COVID-19 worldwide has caused significant changes in social interactions in various sectors, including the education sector, COVID-19 also has a fast and massive spread rate compared to viruses that have existed before. A network analysis from the Cornell campus shows how universities are vulnerable spaces to be a cluster for the spread of COVID-19. The COVID-19 pandemic has forced universities to change their learning methods. Based on the Association of Private Universities (APTSI) coordination data, several private universities in Indonesia are on the brink of bankruptcy due to fewer intake of new students. Muhammadiyah, a progressive Islamic movement that contributes a lot to the education sector, has felt the exact impact of the COVID-19 pandemic. This study aims to analyze PTMA's brand activation activities during the COVID-19 pandemic. Brand activation activity is PTMA's marketing communication strategy in achieving the target of new student acceptance. This research is descriptive qualitative research using a case study approach. The subject of this research is Muhammadiyah Aisyiyah College, based in the Special Region of Yogyakarta. The PTMA subjects consisted of Ahmad Dahlan University, Yogyakarta Muhammadiyah University and Aisyiyah University Yogyakarta. This study indicates that the backbone of brand activation activities carried out by PTMA during the pandemic was assistance and volunteers. PTMA's brand activation activities during this pandemic utilize social media commonly referred to as a strategy for promotion and publication activities. All brand activation activities refer to implementing the university's caturdharma and cited references to the Covid-19 handling policy of the Muhammadiyah Central Executive.

Keywords: Strategy; brand activation; COVID-19; college; Muhammadiyah Aisyiyah

Korespondensi: Erwin Rasyid, S.I.Kom., M.Sc. Universitas Aisyiyah Yogyakarta. Jl. Siliwangi Jl. Ringroad Barat No.63, Sleman, Daerah Istimewa Yogyakarta 55592.Email: erwin.rasyid@unisayogya.ac.id 


\section{PENDAHULUAN}

Pandemi COVID-19 tumbuh dengan begitu cepat sejak awal kemunculannya di Wuhan. Hal tersebut berdasarkan laporan adanya sekelompok pasien pneumonia di Wuhan Cina dilaporkan ke kantor Organisasi Kesehatan Dunia Beijing pada 30 Desember 2019 (Guarner, 2020). Sejak saat itu, virus ini telah berkembang menjadi Pandemi yang tidak hanya mempengaruhi kesehatan manusia. Penyebaran COVID-19 di seluruh dunia telah menyebabkan perubahan besar dalam interaksi sosial di berbagai sektor, termasuk sektor pendidikan.

Total kasus kematian COVID-19 saat ini telah jauh melampaui jumlah dibandingkan dengan virus sejenis seperti SARS dan MERS. COVID-19 juga memiliki tingkat penyebaran yang sangat cepat dan masif dibandingkan dengan virus-virus yang pernah ada sebelumnya. Analisis jaringan dari kampus Cornell menunjukkan bagaimana universitas merupakan ruang yang rentan menjadi kluster penyebaran COVID-19 (Weeden \& Cornwell, 2020). Fakta ini menjadi tantangan khusus bagi institusi pendidikan tinggi dan kehidupan kampus untuk dapat mencegah terjadinya transmisi lokal.

COVID-19 akan memaksa masyarakat untuk memulai transisi menuju kelas virtual untuk pendidikan sarjana dan pascasarjana (Bacow, 2020). Setiap universitas telah menyatakan kebijakan e-learning darurat, semua pengumuman berlangsung antara 6 dan 13 Maret, dengan mayoritas $(60 \%)$ terjadi pada 10/11 Maret (Murphy, 2020). Sementara itu, di Indonesia Kementerian Pendidikan dan Kebudayaan merespons upaya penyebaran COVID-19 di lingkungan Pendidikan dengan mengeluarkan Surat Edaran Nomor 15 Tahun 2020 tentang Pedoman Penyelenggaraan Belajar Dari Rumah Dalam Masa Darurat Penyebaran COVID-19.

Seluruh Perguruan Tinggi di Indonesia terpaksa harus meniadakan pembelajaran tatap muka yang kemudian diganti menjadi pembelajaran full dengan metode daring. Hal ini memaksa dosen dan mahasiswa untuk melakukan adaptasi agar diseminasi ilmu pengetahuan tetap bisa tercapai. Sangat sulit untuk memprediksi seperti apa lanskap pendidikan setelah COVID-19, sebagian besar karena ancaman transisi masyarakat yang ditimbulkan oleh interaksi kampus (Weeden \& Cornwell, 2020).

Pandemi COVID-19 tidak hanya memaksa perguruan tinggi mengubah metode pembelajarannya. Berdasarkan hasil koordinasi Asosiasi Perguruan Tinggi Swasta (APTSI), sejumlah perguruan tinggi swasta di Indonesia terancam mengalami kebangkrutan. Potensi 
tersebut sangat besar terjadi khususnya di PTS yang memiliki jumlah mahasiswa kurang dari 1000 orang. Sekitar $80 \%$ atau 3.616 PTS dari total 4.520 PTS memiliki jumlah mahasiswa di bawah 1000 .

Situasi pandemi COVID-19 diprediksi akan mengakibatkan sebagian besar mahasiswa di PTS tidak mampu untuk membayar uang kuliah mereka. Meskipun sebagian besar kampus telah menyediakan skema beasiswa, namun jumlah yang tersedia belum sebanding dengan jumlah mahasiswa yang membutuhkan. Akibatnya, menjelang penerimaan mahasiswa baru, sebagian besar PTS kesulitan untuk mendapatkan mahasiswa baru.

Muhammadiyah sebagai gerakan dakwah Islam berkemajuan merupakan salah satu organisasi yang banyak berkontribusi di sektor Pendidikan. Tiga aspek utama dari gerakan pembaharuan Muhammadiyahyaitu keagamaan, pendidikan, dan kemasyarakatan (Sutrisna, 2015). Tujuan pendidikan Muhammadiyah lebih dekat dengan teori pendidikan progresif, namun karena fondasinya religius, maka corak Pendidikan Muhammadiyah adalah progresif religius (Ali, 2016).

Hingga November 2018, terdapat sekitar 174 Perguruan Tinggi Muhammadiyah 'Aisyiyah (PTMA) yang tersebar di berbagai wilayah di Indonesia. Muhammadiyah telah menghasilkan beberapa gerakan filantropi yang banyak mempengaruhi perubahan tatanan sosial masyarakat Indonesia (Jinan, 2015). PTMA sebagai salah satu komunitas PTS terbanyak di Indonesia juga merasakan dampak COVID-19 khususnya dalam proses penerimaan mahasiswa baru. Akhirnya, beberapa PTMA kemudian mulai memikirkan cara untuk melakukan aktivitas promosi di tengah situasi yang tidak menentu akibat adanya Pandemi COVID-19.

Selama beberapa tahun terakhir, interaksi antara pelanggan dan merek telah meningkat berlipat ganda karena pertumbuhan persaingan dan munculnya platform media sosial (Kumar, 2020a). Beberapa organisasi yang sukses pun telah mengakui pentingnya interaksi ini dengan berfokus pada keterlibatan pelanggan untuk mendukung kepentingan jangka panjang organisasi (Rodrigues da Costa \& Maria Correia Loureiro, 2019). Untuk memahami bagaimana brand dapat menciptakan nilai, bentuk budaya, dan pengaruh, kita perlu melihat apa saja faktorfaktor yang dapat mendukung hal tersebut.

Loyalitas terhadap suatu brand dipengaruhi oleh seberapa intens pelanggan berinteraksi dengan merek tersebut. Keterlibatan pelanggan mengacu pada keadaan psikologis yang berkembang sebagai hasil dari pengalaman interaktif pelanggan dengan perusahaan atau suatu merek (Brodie et al., 2011). Partisipasi pelanggan merupakan salah satu bagian penting dari kinerja sukarela pelanggan yang 
ditunjukkan dalam perilaku pelanggan ke perusahaan (Leckie et al., 2016).

Perusahaan berupaya untuk tetap eksis di antara persaingan brand dari perusahaan yang sejenis dan melakukan strategi strategi unik untuk mendapat perhatian publik, salah satunya dengan melakukan brand activation (Lubis \& Ganiem, 2017). Dalam hal ini, PTMA tidak hanya menghadapi persaingan antar sesama PTS, namun juga berada ditengah persaingan dengan Perguruan Tinggi Negeri.

Salah satu bentuk strategi yang dilakukan oleh PTMA untuk tetap mempertahankan eksistensi mereka yaitu melalui strategi brand activation. Brand activation bertujuan untuk meningkatkan komunikasi terhadap khalayak dengan cara lebih baik serta komunikasi yang terbentuk diharapkan dapat meningkatkan penjualan dan juga dapat memposisikan brand pada posisi tertentu sesuai tujuan organisasi (Liembawati et al., 2014).

Brand dapat diaktivasi dalam berbagai bentuk, di antara product and service (barang dan jasa), employees (karyawan), identity (identitas), dan communication (komunikasi). Namun, tidak semua perusahaan menerapkan aktivasi merek untuk empat aspek yang disebutkan di atas. Itu hanyalah pilihan. Beberapa perusahaan lebih banyak hanya melakukan brand activation pada aspek komunikasi (Morel, 2002).

Merek merupakan bagian inti dari aktivitas komunikasi pemasaran. Berangkat dari sudut pandang konsumen, mereka memiliki pandangan bahwa merek terbaik adalah merek yang mampu merepresentasikan karakter produk yang sesungguhnya (Ayu Retno Widyastuti et al., 2018). Konsep connected marketing yang dikemukakan Paul Marsden, event atau brand activation merupakan salah satu cara dalam menciptakan buzz marketing atau pembicaraan (word of mouth) yang positif tentang perusahaan, produk, atau jasa oleh media dan publik.

Program brand activation semakin nyata diperlukan karena saat masyarakat sudah semakin pintar dan tidak bisa lagi didekati dengan aktivitas periklanan konvensional yang sifatnya satu arah (Yusuf, 2016). Brand loyalty sedikit banyak memiliki hubungan dengan kontak langsung maupun tidak langsung dengan konsumen (Ratriyana, 2019). Salah satu bentuk kontak langsung atau komunikasi pemasaran yang dapat dilakukan dengan konsumen yaitu melalui aktivitas brand activation .

Berdasarkan latar belakang di atas, penelitian ini kemudian ingin melihat bagaimana aktivitas promosi PTMA dalam situasi pandemi COVID-19. Tema terkait consumer engagement telah banyak menarik perhatian dari para peneliti dan praktisi akademis. Oleh karena itu, penelitian ini berusaha untuk mengkaji bagaimana aktivitas brand activation 
PTMA di masa Pandemi COVID-19. Mengkaji sejauh mana strategi strategi brand activation yang diterapkan PTMA dalam mencapai target penerimaan jumlah mahasiswa baru.

\section{METODE PENELITIAN}

Penelitian ini merupakan jenis penelitian kualitatif deskriptif. Penelitian kualitatif mensyaratkan cara berpikir yang menangkap berbagai fakta atau fenomena sosial melalui pengamatan, lalu melakukan analisis dan teorisasi berdasarkan apa yang ditemukan di lapangan (Bungin, 2007). Terdapat tiga tahapan dalam proses penelitian kualitatif. Tahap pertama yaitu orientasi, pada tahap ini peneliti menemukan fenomena yang akan diobservasi. Kedua, yaitu tahap reduksi merupakan tahapan di mana peneliti memilih data yang menarik dan penting untuk dikategorikan. Ketiga yaitu tahapan seleksi, pada tahap ini data yang telah dikategorikan, kemudian diinterpretasi dan dideskripsikan lebih rinci.

Pendekatan yang digunakan dalam penelitian ini adalah studi kasus. Studi kasus merupakan salah satu metode penelitian ilmu-ilmu sosial. Secara umum studi kasus merupakan strategi yang lebih cocok bila pokok pertanyaan suatu penelitian berkenaan dengan "how" dan "why", bila peneliti hanya memiliki sedikit peluang untuk mengontrol peristiwaperistiwa yang akan diselidiki dan bilamana fokus penelitiannya terletak pada fenomena kontemporer didalam konteks kehidupan nyata (Yin, 2006). Penggunaan jenis dan pendekatan penelitian tersebut didasarkan pada alasan subjek yang diteliti yaitu aktivitas brand activation Perguruan Tinggi Muhammadiyah Aisyiyah yang ada di Daerah Istimewa Yogyakarta.

Subjek dari penelitian ini yaitu Perguruan Tinggi Muhammadiyah Aisyiyah (PTMA) yang berbasis di Daerah Istimewa Yogyakarta. PTMA tersebut terdiri dari Universitas Ahmad Dahlan, Universitas Muhammadiyah Yogyakarta, dan Universitas Aisyiyah Yogyakarta. Subjek dibagi menjadi tiga kluster kampus yaitu kampus unggul, menengah, dan berkembang. Masingmasing dari kampus yang menjadi subjek dalam penelitian ini telah merepresentasikan dari kluster subjek yang dibuat.

Metode pemilihan informan dalam penelitian ini menggunakan teknik purposive sampling, yakni informan dipilih secara sengaja berdasarkan kriteria yang ditentukan oleh peneliti (Singarimbun dan Effendi, 2011). Informasi terkait aktivitas brand activation diperoleh dari biro admisi dan hubungan masyarakat masing-masing kampus. Artinya informan dalam penelitian ini adalah staf dan karyawan yang bekerja pada bidang promosi dan hubungan masyarakat dari tiga kampus yang menjadi subjek penelitian. Pengumpulan data diperoleh dari hasil observasi, wawancara, 
dokumentasi.

Data yang diperoleh melalui wawancara mendalam didasarkan pada interview guide yang disusun sebagai pedoman untuk membatasi perolehan data di lapangan agar tidat terlalu meluas (Moelong, 2007). Interview guide dalam penelitian ini disusun berdasarkan teori yang digunakan kemudian akan ditanyakan pada informan yang telah ditentukan sebelumnya. Interview guide akan disesuaikan dengan fokus penelitian untuk menjawab rumusan masalah dan tujuan penelitian ini.

Proses observasi dalam penelitian dilakukan dengan mengamat dan mencermati setiap peristiwa yang berkaitan penelitian ini. Peneliti dalam hal ini bertindak sebagai observer non-partisipan. Peneliti tidak terlibat secara langsung untuk bagaimana pekerjaan dilakukan, tetapi data dapat diperoleh dengan mengamati dan mencatat aktivitas yang ada. Peneliti mengamati bagaimana aktivitas brand activation masing-masing kampus yang menjadi subjek dalam penelitian ini.

Pengumpulan data melalui teknik dokumentasi dilakukan dengan mengumpulkan beberapa bahan yang berkaitan dengan strategi brand activation PTMA di masa Pandemi COVID-19. Data yang didokumentasikan dalam bentuk audio maupun audio visual, kemudian diterjemahkan dalam bentuk teks sesuai dengan kebutuhan penelitian. Sementara itu, data visual berupa foto dapat digunakan sebagai informasi tambahan untuk mempertegas narasi yang akan disampaikan. Untuk menguji keabsahan data dalam penelitian ini, maka digunakan beberapa teknik untuk menguji validitas data yang diperoleh. Validasi data penting untuk dilakukan untuk mengukur sejauh mana data yang diperoleh dapat dipercaya. Adapun teknik yang digunakan untuk mengukur validitas data dalam penelitian yaitu triangulasi data.

Metode analisis data yang digunakan dalam penelitian ini adalah Teknik analisis data interaktif. Teknik analisis data yang digunakan dalam penelitian ini adalah teknis analisis data model interaktif. Teknis tersebut terdiri atas empat tahapan yang harus dilakukan. Tahapan pertama adalah tahapan pengumpulan data, tahapan kedua adalah reduksi data, tahapan ketiga adalah tahap menampilkan data, dan tahap yang keempat adalah tahap penarikan kesimpulan dan/atau tahap verifikasi (Herdiansyah, 2010).

\section{HASIL DAN PEMBAHASAN}

Kegiatan brand activation Perguruan Tinggi Muhammadiyah Aisyiyah (PTMA) tidak terlepas dari peranan Persyarikatan Muhammadiyah dalam merespons dampak Pandemi COVID-19. Aktivitas tersebut diwujudkan dengan konsep kolaborasi di bawah naungan lembaga Muhammadiyah COVID-19 
Command Center (MCCC). Melalui beragam kegiatan sosialisasi secara daring maupun luring, PTMA secara kolektif membangun beberapa kegiatan yang mampu mendukung aktivitas brand activation di masa Pandemi.

MCCC yang berpusat di Yogyakarta membuka peluang PTMA yang ada di wilayah tersebut untuk ikut berpartisipasi aktif dalam setiap kegiatan yang dilaksanakan. Di Daerah Istimewa Yogyakarta, terdapat tiga PTMA di antaranya Universitas Muhammadiyah Yogyakarta, Universitas Ahmad Dahlan dan Universitas Aisyiyah Yogyakarta.

Universitas Muhammadiyah Yogyakarta (UM Yogyakarta) menjadi pelopor yang aktif dalam kegiatan brand activation pada masa pandemi COVID-19. UM Yogyakarta dikenal memiliki slogan Muda Mendunia dengan berbagai macam program-program promosi dan pemasaran baik yang bersifat hard selling maupun soft selling. Slogan Muda Mendunia menjadi penciri utama kegiatan promosi dan publikasi UM Yogyakarta dan digunakan sejak tahun 2013.

Pada bulan Februari 2020, UM Yogyakarta telah menjalin kerjasama dengan Kementerian Kesehatan dan Majelis Diklitbang Muhammadiyah menerapkan konsep kampus sehat. Langkah ini merupakan respons awal UM Yogyakarta menghadapi pandemi COVID-19. Kegiatan tersebut juga merupakan bagian dari cara UM Yogyakarta dalam menjalankan strategi brand activation di masa Pandemi COVID-19.

Di awal Juli 2020, UM Yogyakarta mengadakan kegiatan "Rektor Menyapa". Rektor UM Yogyakarta Dr. Budi Gunawan memberikan penjelasan terkait data yang menunjukkan bahwa, dari 104 kampus di Yogyakarta hanya 12,5\% yang bisa bertahan di tengah situasi Pandemi COVID-19. Kegiatan tersebut merupakan bentuk strategi komunikasi krisis yang diberikan pimpinan Universitas kepada seluruh stakeholder yang ada di UM Yogyakarta.

Sejak awal bulan Maret 2020, UM Yogyakarta memberikan beberapa respons awal dalam mengantisipasi dampak yang ditimbulkan oleh Pandemi COVID-19. Di antaranya, Mahasiswa UM Yogyakarta menerima subsidi kuota internet dan bantuan logistik berupa sembako. Pembebasan beberapa biaya kuliah seperti potongan SPP sampai $20 \%$. Selain itu, dosen dan karyawan juga diberikan bantuan berupa uang belanja Ramadhan, lauk pauk, sembako, tunjangan hari raya hingga parsel saat Idul Fitri.

UM Yogyakarta juga melakukan beberapa kegiatan brand activation yang cukup beresiko. Disebut berisiko karena tidak sejalan dengan pemahaman dalam pelaksanaan program yang menerapkan protokol kesehatan yang ketat. 
Misalnya keputusan untuk melaksanakan wisuda luring pertama di masa pandemi dengan penerapan protokol kesehatan yang ketat.

"Pelaksanaan wisuda luring ini telah mendapatkan persetujuan dari MCCC, kita juga telah melaksanakan protokol kesehatan secara ketat". Rasyid, E. Putranto, A. P. W. T (Interviewer) \& Mr. Mawardi (Interviewee). 2020.

Program ini kemudian viral di media sosial dan mendapatkan beberapa komentar positif positif di media sosial. Efek yang ditimbulkan dari program wisuda luring di tengah pandemi ini menjadi salah satu lompatan dan inovasi yang penting bagi aktivitas brand activation yang dilakukan oleh UM Yogyakarta. Melalui pelaksanaan wisuda luring tersebut, UM Yogyakarta membentuk persepsi yang positif bagi khalayak.

Salah satu efek dari program wisuda luring menjadikan UM Yogyakarta sebagai salah satu universitas paling populer di media sosial. Publikasi di media sosial adalah salah satu strategi yang efektif di masa pandemi untuk dapat semakin mengenalkan eksistensi brand UM Yogyakarta kepada masyarakat. Loyalitas terhadap suatu merek dipengaruhi oleh seberapa intens pelanggan berinteraksi dengan merek tersebut. Keterlibatan pelanggan mengacu pada keadaan psikologis yang berkembang sebagai hasil dari pengalaman interaktif pelanggan dengan organisasi atau suatu brand (Brodie et

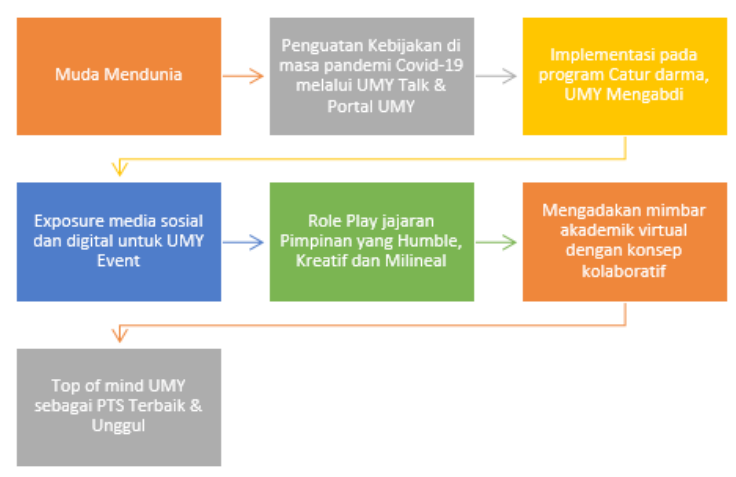

Sumber: Akun Instagram UMY, 2020 Gambar 1 Postingan official account Instagram @
umyogya

al., 2011).

Persepsi positif merupakan instrumen penting setiap pelaksanaan aktivitas brand activation. Untuk mengantisipasi timbulnya persepsi negatif, wacana dominan perlu dilakukan pemberian edukasi bernada positif kepada khalayak. Edukasi ini juga merupakan salah satu langkah yang harus dilakukan dalam rangka membangun merek dengan menggunakan komunikasi yang bersifat persuasif.

Partisipasi khalayak merupakan salah satu bagian penting dari kinerja sukarela yang ditunjukkan dalam perilaku ke organisasi (Leckie, Nyadzayo \& Johnson, 2016). Konsep ini kemudian diterjemahkan ke dalam progam UM Yogyakarta mengabdi. Program UM Yogyakarta mengabdi ini diwujudkan dengan kontribusi sivitas akademika dalam penanggulangan COVID-19. Tujuan dari 


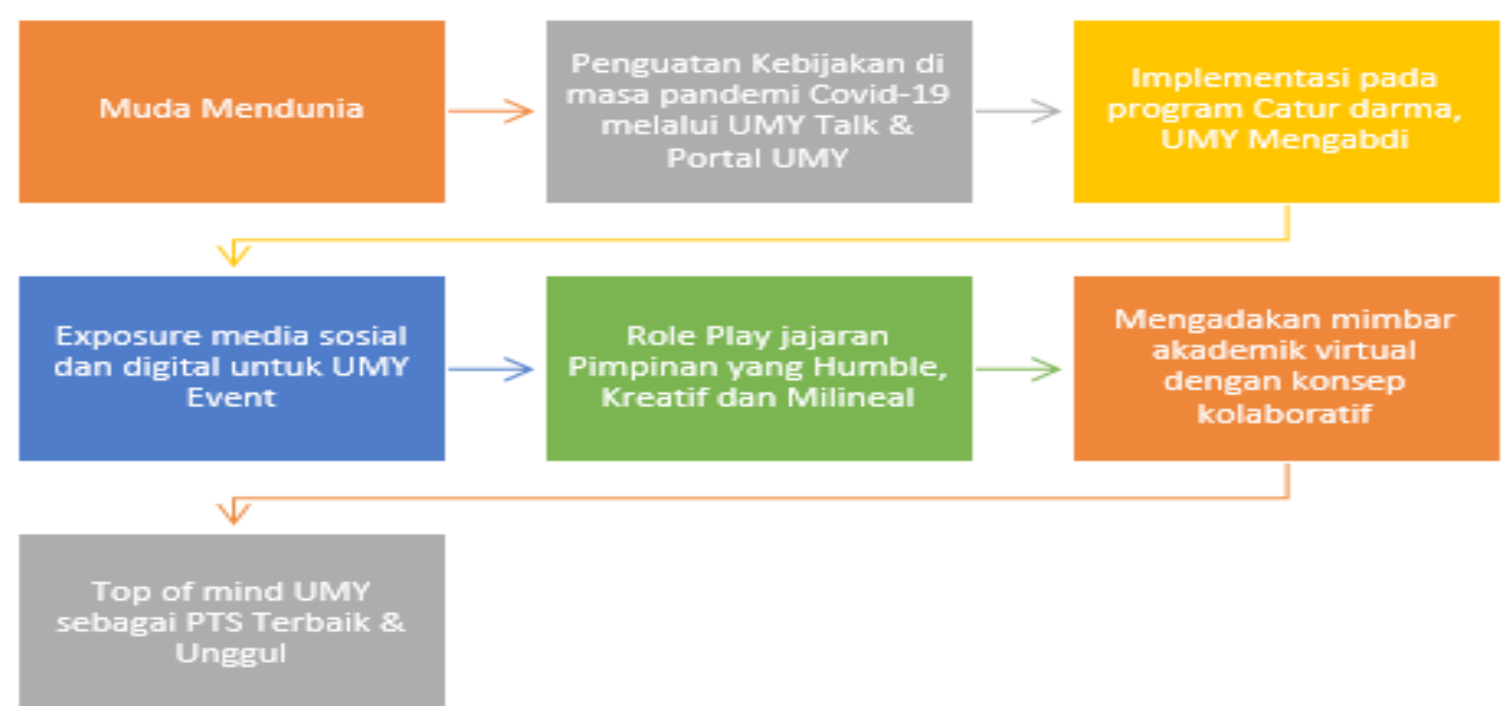

Sumber: Olah data Peneliti, 2020

\section{Gambar 2 Bagan Brand Activation}

program UM Yogyakarta mengabdi ini adalah untuk lebih meningkatkan keterikatan sivitas UM Yogyakarta dengan masyarakat sebagai bagian dari strategi brand activation .

\section{Program UMY Mengabdi menyasar} berbagai sektor, mulai dari daerah 3T (terluar, terdalam dan tertinggal) hingga zona-zona merah dan hitam pandemi COVID-19. Pelaksanaan UMY Mengabdi juga diintegrasikan ke dalam program KKN UM Yogyakarta serta berbagai kegiatan virtual yang dilaksanakan oleh MCCC.

Selain melalui program KKN di masa Pandemi, UM Yogyakarta juga secara konsisten menyelenggarakan kegiatan UMY Talks. UMY Talks merupakan program siaran berformat talk show podcast. Melalui media podcast tersebut, UM Yogyakarta mampu menghadirkan ruangruang interaksi yang dapat dimanfaatkan oleh khalayak.
UMY Talks tidak hanya menjadi sarana untuk menyampaikan kebijakan-kebijakan di masa pandemi. Program tersebut juga dapat menjadi sarana interaksi virtual yang digunakan sebagai wujud role-play sivitas akademika UM Yogyakarta.

Pelaksanaan kegiatan brand activation adalah memberikan pengalaman positif kepada khalayak yang menjadi sasaran kegiatan. Pengalaman tersebut diharapkan mampu memberikan stimulus positif untuk agar brand UM Yogyakarta diterima dengan baik oleh khalayak atau pengguna. Berikut ini gambaran dari alur pelaksanaan strategi brand activation UM Yogyakarta, dapat dilihat pada gambar 2.

Dari pemaparan data di atas, media digital dianggap sebagai medium komunikasi yang efektif dalam menghubungkan institusi dengan khalayaknya secara lebih personal dan tepat 
sasaran. Konsep media digital mengacu kepada hyper competitive yang dapat membentuk titik temu antara brand dan khalayak. Khalayak dipandang sebagai user yang dapat menunjukkan kekuatan untuk memilih dengan sadar dan berpartisipasi secara aktif. Partisipasi ini yang kemudian menjadi equity yang berpengaruh signifikan terhadap peningkatan brand loyalty. UM Yogyakarta mewujudkan strategi tersebut dengan memperhatikan brand positioning melalui berbagai macam aktivitas brand activation.

Sementara itu, di masa awal pandemi Universitas Ahmad Dahlan Yogyakarta (UAD) menghadapi persoalan di media sosial. Kemunculan tagar \#UADDown di beberapa platform media sosial opini yang bernada negatif terhadap UAD. Tagar ini muncul akibat ketidakpuasan sivitas akademika terhadap kebijakan-kebijakan yang diterapkan oleh UAD. Tagar ini menjadi viral sehingga membuat UAD kesulitan dalam melakukan aktivitas promosi dan brand activation. Peristiwa ini menunjukkan bahwa, kekuatan dari publik internal merupakan potensi yang dikelola dengan baik. Perlu pendekatan secara masif yang terorganisir untuk mengelola opini negatif yang berasal dari publik-publik internal.

UAD menjalankan serangkaian program yang bersifat edukasi untuk merespons keresahan yang dialami oleh publik internalnya.

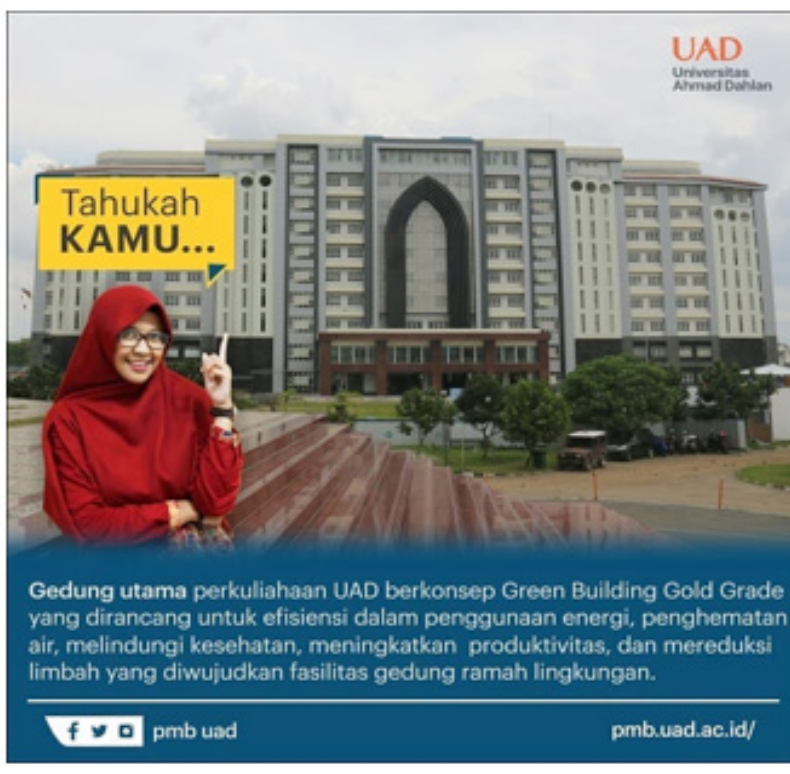

Sumber: PMB UAD, 2020

Gambar 3 UAD Building Konsep

Tagar ini menjadi langkah awal bagaimana UAD bertindak, berkreativitas dan aktif untuk menjalankan kegiatan brand activation. UAD menerapkan strategi branding melalui pesona kampus terpadu sebagai kampus yang futuristik, modern, dan ramah lingkungan. Gedung kampus terpadu dibuat menjadi sangat ikonik hingga mampu dikenal sebagai kampus yang megah dan modern.

UAD menggunakan lima teknik aktivasi merek diantaranya: 1). Marketing Event Activation: Activation ini dikemas dalam bentuk event. Dengan memberikan experience langsung kepada konsumen yang datang. Biasanya event akan diberi tema sesuai produk yang akan di promosikan, lalu disajikan content activity yang menarik. Contohnya pada event P2K (Program Pengenalan Kampus) yang 
dilakukan setiap penerimaan mahasiswa baru mampu membuat aktivitas ini menjadi viral dan dikenal. 2). Promotion Activation: Activation ini menyajikan kegiatan promosi seperti promo spesialnewlauching, undian berhadiah, kemasan spesial dan lain sebagainya. Contohnya: UAD memperkenalkan merchandise yang terbilang unik, yaitu peralatan kuliah yang identik dengan warna orange yang menjadi penciri UAD. 3). Sponsorship Activation: Activation jenis ini dikemas dalam bentuk pendanaan event yang diselenggarakan oleh pihak di luar perusahaan. Sehingga perusahaan dapat berpromosi pada event tersebut. UAD melakukan aktivasi sponsor dengan aktif memerangi pandemi COVID-19 melalui Muhammadiyah COVID-19 Command Center dengan memberikan sumbangsih nyata baik dari keluasan keilmuan dan aktif dalam pemberian bantuan. 4). Direct Marketing Activation: Activation ini dikemas dalam bentuk interaksi langsung dengan konsumen melalui wawancara via televisi, radio, media cetak dan lain sebagainya. UAD memiliki TV UAD dan UAD Radio yang mewadahi penyiaran UAD kepada khalayak. Pada masa pandemi ini UAD juga mempunyai sarana podcast yang mewadahi informasi dan pemberian informasi dengan kemasan yang ramah terhadap remaja. 5). Social Media Activation: Activation ini dilakukan melalui platform media sosial. Seperti melakukan social media campaign, giveaway, endorse dan lain sebagainya. Untuk Program KKN UAD pada masa pandemi ini dikenal dengan program Orange Expedition. Program KKN ini di lakukan di kampung Lamahan Pulau Buru, Maluku oleh Dodi Irawan Kaliki dan Azmia Aisyah yang di dokumentasikan melalui media film dokumenter.

Penggunaan kelima teknik brand activation tersebut menunjukkan bahwa UAD serius untuk melakukan re-branding agar tidak terjadi lagi tagar UAD-down atau semacamnya, terlebih dikala pandemi yang membatasi segala sendi kehidupan dan aspek ekonomi bahkan sosial kemasyarakatan. UAD berkomitmen dengan memberikan kesempatan seluas-luasnya untuk memberikan saran, masukan, dan opini yang relevan dengan kebijakan-kebijakan yang dikeluarkan oleh UAD. Hal ini menjadikan suatu proses dan ekosistem yang baik bagi perjalanan kampus UAD dalam memberikan yang terbaik untuk publik.

Pada aktivitas penerimaan mahasiswa baru, UAD memberikan kesempatan kepada para siswa SMA/MA/SMK untuk dapat mengakses informasi seputar pendaftaran sampai biaya secara sentralistis dan accsessible. Selain itu, UAD juga menghadirkan tagar \#WeAreUAD yang berarti kita adalah UAD. Tagar tersebut merupakan bentuk personifikasi UAD dalam merespons opini negatif yang muncul di media sosial. 
UAD menyadari kekuatan baru dalam berkomunikasi ada di media sosial. Kekuatan tersebut didukung oleh karakter-karakter yang mampu menanggulangi aspirasi bernada negatif yang telah terjadi, berikut ulasannya: 1). Partisipasi: media sosial mendorong kontribusi dan umpan balik dari setiap orang yang tertarik. 2). Keterbukaan: layanan media sosial terbuka untuk umpan balik dan partisipasi, 3). Percakapan: saat media tradisional masih mendistribusikan konten ke khalayak, media sosial dikenal lebih baik dalam komunikasi dua arah. 4). Komunitas: media sosial dapat membentuk komunitas dengan cepat. 5). Konektivitas: kebanyakan media sosial berkembang pada keterbukaan ke situs-situs lain, sumber-sumber lain, dan orang-orang lain.

UAD melakukan strategi dengan mengidentifikasi karakteristik pelanggan dengan menitikberatkan pada sifat "sosial" . Pertama, status dan self esteem menjadi cubitan pertama dalam mengasosiasikan pesan promosi UAD. Dalam piramida kebutuhan psikologis manusia, pencapaian dan penghargaan dari orang lain disebut sebagai kebutuhan tertinggi setelah aktualisasi diri. UAD melakukan program edukasi dan promosi berdasarkan kebutuhan pelanggannya menjadi benang merah yang digaungkan. Buah dari program edukasi yang digencarkan ini kemudian menciptakan sebuah afiliasi untuk menjadi bagian dari sesuatu yang besar, tentu menjadi "Dahlan Muda" menjadi sense of belonging yang dijual.

Kampus PTMA ketiga di Yogyakarta yang banyak melakukan aktivitas brand activation yaitu Universitas Aisyiyah Yogyakarta. Kegiatan brand activation yang dilakukan oleh UNISA Yogyakarta yaitu mengadakan program promosi yang berbasis digital dengan konsep "UNISA Bergerak" dan “UNISA Gumregah”.

UNISA Yogyakarta berfokus pada pembuatan konten untuk kebutuhan brand activation dengan semangat UNISA Gumregah.

Kata gumregah diartikan sebagai semangat yang berasal dari kosa kata Bahasa Jawa.

Kata gumregah difokuskan untuk calon mahasiswa agar memberikan energy positif dengan tetap bersemangat untuk meraih cita-cita dengan menjadi sarjana. Rasyid, E. Putranto, A. P. W. T (Interviewer) \& Mr. Komarudin (Interviewee). 2020.

UNISA Yogyakarta juga memanfaatkan digital platform dengan mengintegrasikan berbagai sosial media sebagai saluran edukasi dan pemasaran. Berikut diagram bentuk strategi integrasi sosial media UNISA Yogyakarta dalam aktivitas brand activation yang mereka lakukan.

Dungeon terdiri dari publik yang berfokus pada teknologi yang memfasilitasi fantasi dan permainan. Istilah rooms menunjukkan lingkungan yang dibentuk karena mediasi komputer di mana public secara kolektif berkumpul bersama dan berinteraksi dalam 


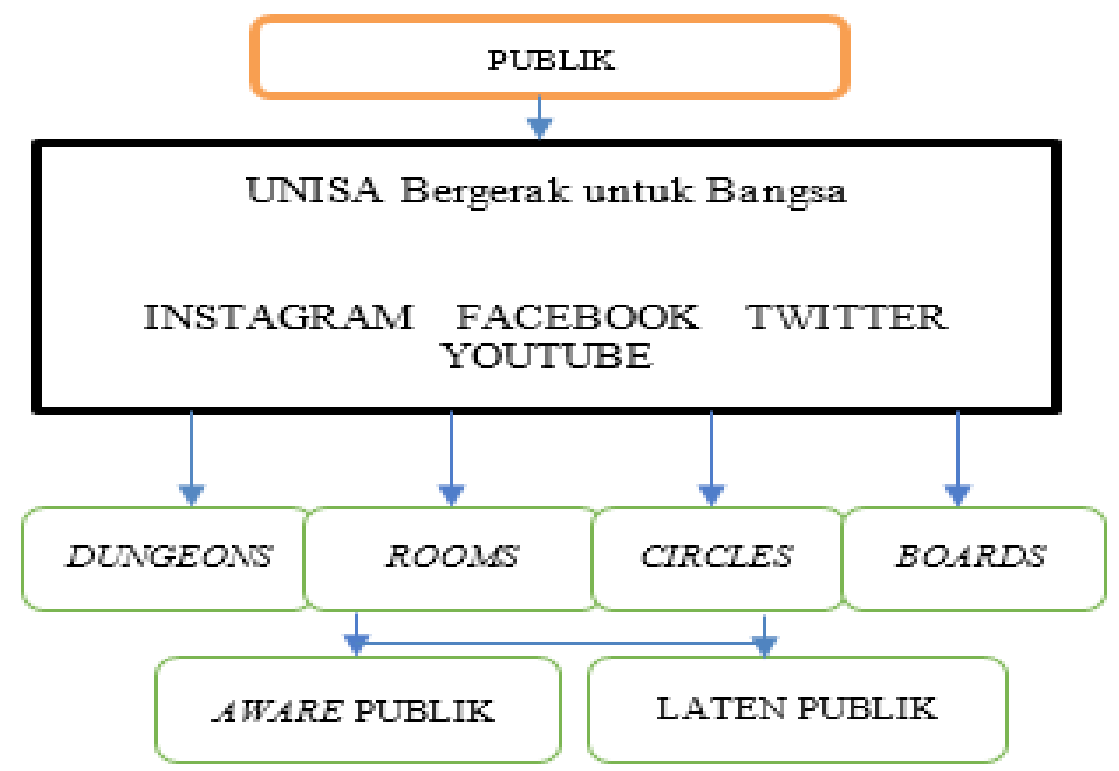

Sumber: Olah data Peneliti, 2020

\section{Gambar 4 Strategi Integrasi Sosial Media UNISA Yogyakarta}

waktu nyata tanpa adanya struktur tertentu yang diambil oleh fantasi mereka. Circles adalah jalinan yang saling menghubungkan homepages maupun kumpulan-kumpulan yang terstruktur oleh minat dan berorientasi pada penyediaan informasi. Board adalah komunitas-komunitas online yang teroganisir oleh buletin elektronik. Publik menjadi tersegmentasi secara "natural" ketika sebuah program digital yang bersifat menjual dihadirkan ke dunia online. Kedua kutub besar inilah yang menentukan program digital tersebut dapat menyentuh lapisan atau tidak. Adaptasi dari teori yang dikemukakan oleh Kozinets yang memetakan konsumen dapat diartikan sebagai publik yang potensial (Kozinets et al., 2007)

Slogan UNISA Bergerak untuk Bangsa diartikan sebagai upaya edukasi dan promosi dengan memanfaatkan publik internal sebagai salah satu sumberdaya yang dimiliki UNISA. Adanya pembagian segmentasi tersebut, diharapkan konten promosi dan publikasi juga akan memiliki konsep yang terarah sesuai dengan yang diharapkan. Konsep integrasi media sosial ini juga menghadirkan cara promosi dengan berbasis story telling atau bercerita. Selain melalui kegiatan tersebut, UNISA Yogyakarta UNISA Yogyakarta juga meluncurkan buku yang berjudul UNISA menulis COVID-19.

Story telling menjadi strategi untuk memberikan ruang mengekspresikan diri dan dan bersifat testimoni. Konsep inilah yang menjadi kekuatan koneksi yang dilipatgandakan untuk menghasilkan sense of community. 


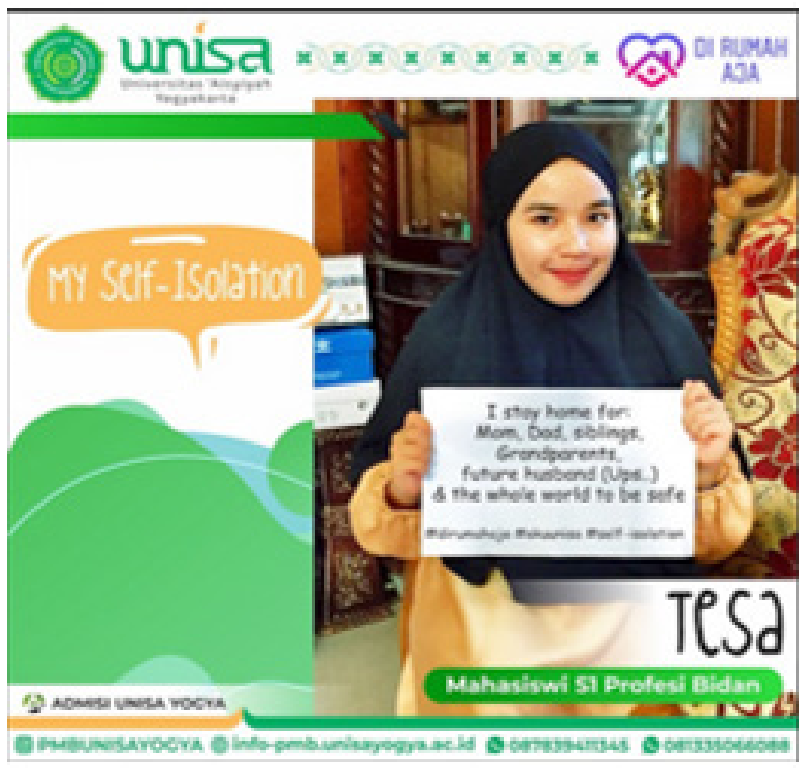

Sumber: Instagram @pmbunisayogya,2020

Gambar 5 Konsep Twiboon UNISA Yogyakarta

Karakteristik sosial ini bertumpu pada kisah heroic senasib dan sepenanggungan yang dialami. Interaksi yang mampu menghadirkan dan memenuhi kebutuhan rasional serta kebutuhan emosional hingga spiritual. UNISA menciptakan komunitas online yang berinteraksi dengan bercerita atau storytelling.

Selain sebagai media promosi, UNISA Yogyakarta juga memanfaatkan media sosial juga sebagai alat brand activation. Seperti yang dilakukan oleh UNISA Yogyakarta melalui kampanye di sosial media melalui fitur twibbon. Desain twibbon UNISA Yogyakarta menunjukkan identitas sebagai nuansa kampus berwawasan kesehatan. Twibbon tersebut menunjukkan bahwa kegiatan promosi dan publikasi bersifat soft selling dapat menyasar target yang lebih luas, dapat dilihat pada gambar
5.

Ruang lingkup program promosi digital UNISA Yogyakarta mencakup empat instrumen penting yang melatar belakangi konten yang disajikan di media sosial. Konsep ini tersebut dijadikan sebagai rencana strategi Biro Admisi UNISA Yogyakarta dalam dokumen rapat kerja persiapan promosi UNISA Yogyakarta.

UNISA Yogyakarta berusaha untuk tetap mengikuti tren yang berkembang dengan menyasar serta memperhatikan tipografi dan demografi khalayak. Dilihat dari perspektif ini, remaja telah memiliki kemandirian dalam menentukan keputusan masa depannya dan tidak bergantung pada orang tua. Selanjutnya adalah faktor influencer. Dalam satu keluarga, anggota-anggotanya saling berinteraksi dan saling mempengaruhi satu dengan lainnya. Ketika memberikan dan menentukan sesuatu, peran-peran ini lah yang perlu diperhatikan. Aktor yang memiliki pengaruh dalam pengambilan keputusan menjadi target yang disasar oleh UNISA Yogyakarta.

Di masa pandemi, kegiatan brand activation menuntut PTMA untuk mampu memanfaatkan media sosial sebagai sarana promosi. Ketiga kampus yang diteliti telah menunjukkan strategi promosi dengan menggunakan media sosial. Hal tersebut dapat dilihat dalam Tabel 1 analisis aktivitas Brand Activation PTMA .

Keterlibatan brand dengan konsumen 
Tabel 1 Strategi Brand Activation PTMA Melalui Media Sosial Instagram

\begin{tabular}{|c|c|c|c|}
\hline Tahapan & UNISA Yogyakarta & UM Yogyakarta & UAD \\
\hline $\begin{array}{l}\text { Analisa Media yang } \\
\text { pernah dan sedang } \\
\text { digunakan }\end{array}$ & $\begin{array}{l}\text { UNISA Yogyakarta } \\
\text { menggunakan dua } \\
\text { media, termasuk } \\
\text { website resmi } \\
\text { untuk membumikan } \\
\text { brand dari UNISA } \\
\text { Yogyakarta }\end{array}$ & $\begin{array}{l}\text { UMY menjadi kampus } \\
\text { yang menunjukkan } \\
\text { semangat muda } \\
\text { mendunia dengan } \\
\text { mengekspansi fungsi } \\
\text { media sosial secara } \\
\text { masif }\end{array}$ & $\begin{array}{l}\text { UAD memiliki media } \\
\text { alternatif yang mampu } \\
\text { mengonter isu, di } \\
\text { samping itu UAD } \\
\text { mengekspansi fungsi } \\
\text { media sosial secara } \\
\text { masif layaknya UMY }\end{array}$ \\
\hline Trinitas Media Sosial & $\begin{array}{l}\text { Sebagai sebuah } \\
\text { kampus tahapan } \\
\text { berkembang UNISA } \\
\text { menggunakan media } \\
\text { instagram dan website } \\
\text { resmi sebagai ujung } \\
\text { tombak kegiatan } \\
\text { promosi, publikasi } \\
\text { dan kegiatan brand } \\
\text { activation }\end{array}$ & $\begin{array}{l}\text { UMY menggunakan } \\
\text { kelima media sosial } \\
\text { dengan hasil analisis } \\
\text { mendalam serta yang } \\
\text { memilik pengaruh } \\
\text { besar (Facebook, } \\
\text { website, resmi, tik-tok, } \\
\text { twitter, Instagram) }\end{array}$ & $\begin{array}{l}\text { UAD menggunakan } \\
\text { strategi yang lebih } \\
\text { masif dengan } \\
\text { memanfaatkan media } \\
\text { sosial pada konten } \\
\text { yang bersifat lebih } \\
\text { milenial, seperti } \\
\text { Instagram }\end{array}$ \\
\hline Strategi Terintegrasi & $\begin{array}{l}\text { Berbasis konten } \\
\text { dengan cakupan } \\
\text { aktivitas mahasiswa, } \\
\text { peristiwa, dan event } \\
\text { kampus }\end{array}$ & $\begin{array}{l}\text { Fokus pada role play } \\
\text { dan public figure } \\
\text { yang tercipta di media } \\
\text { sosial }\end{array}$ & $\begin{array}{l}\text { Konten UAD } \\
\text { Yogyakarta fokus pada } \\
\text { pengenalan kampus } \\
\text { dan konten arus balik }\end{array}$ \\
\hline Sumber-sumber & $\begin{array}{l}\text { Pengenalan kepada } \\
\text { masyarakat perubahan } \\
\text { merek dari sekolah } \\
\text { tinggi kesehatan } \\
\text { menjadi }\end{array}$ & $\begin{array}{l}\text { Pengenalan pada } \\
\text { sosok-sosok yang } \\
\text { dimiliki UMY mulai } \\
\text { dari jajaran Rektorat, } \\
\text { Dekanat, Dosen dan } \\
\text { mahasiswa berprestasi }\end{array}$ & $\begin{array}{l}\text { Pengenalan konsep } \\
\text { green building } \\
\text { KPT UAD sebagai } \\
\text { trademark baru } \\
\text { kampus modern, } \\
\text { futuristik dan ramah }\end{array}$ \\
\hline $\begin{array}{l}\text { Implementasi dan } \\
\text { Pengukuran }\end{array}$ & $\begin{array}{l}\text { Jumlah mahasiswa } \\
\text { yang masuk dan } \\
\text { mendaftar sebagai } \\
\text { mahasiswa UNISA }\end{array}$ & $\begin{array}{l}\text { Eksposur pada website } \\
\text { resmi UM Yogyakarta } \\
\text { melalui pengukuran } \\
\text { webomatic dan } 4 \text { ICU }\end{array}$ & $\begin{array}{l}\text { Eksposur media } \\
\text { pada pemeringkatan } \\
\text { rangking PTS versi } \\
\text { kemendikbud dsb }\end{array}$ \\
\hline
\end{tabular}

Sumber: Hasil Analisis Data Peneliti, 2020

dapat ditingkatkan melalui konten di situs jejaring sosial yang menyesuaikan pengalaman khalayak waktu ke waktu (Demmers et al., 2020). Pengalaman inilah yang kemudian dimanfaatkan oleh PTMA untuk semakin menegaskan posisi brand mereka di masa Pandemi COVID-19. Organisasi yang baik akan memanfaatkan pentingnya interaksi ini dan karenanya berfokus untuk melibatkan khalayak agar memiliki keunggulan kompetitif jangka panjang yang berkelanjutan (Rodrigues \& Maria, 2019).

Beberapa hasil riset juga menunjukkan bagaimana pentingnya media sosial sebagai alat pemasaran di masa Pandemi COVID-19. Media sosial dapat menjadi alat untuk memengaruhi setiap perilaku dan pengambilan keputusan serta penggunaan suatu brand oleh khalayak. Media sosial menjadi alat pemasaran yang penting untuk membangun merek, terutama 
yang berkaitan dengan membangun kesadaran terhadap suatu merek (Mason et al., 2021).

Praktik kehumasan khususnya dalam aktivitas brand activation telah banyak berubah di masa Pandemi COVID-19. Hal ini dipengaruhi oleh COVID-19 yang banyak mengubah kebiasaan dan pola interaksi manusia. Kampanye kehumasan saat ini perlu mempertimbangkan dan mengoptimalkan platform digital baru sebagai alat analitik untuk mendukung pemasaran (Gendron, 2017).

Strategi brand activation pada dasarnya telah menggeser paradigma pemasaran tradisional. Brand activation tidak hanya diukur dari hasil penjualan melainkan diukur dari segi kesadaran dan visibilitas. Tujuan dari brand activation yaitu untuk menciptakan loyalitas merek dan mendapatkan kepercayaan pelanggan. Hal ini penting dilakukan oleh PTMA untuk menghadapi tantangan yang dihadirkan oleh Pandemi COVID-19.

Aktivitas brand activation dapat dimanfaatkan sebagai strategi untuk membuat positioning dan arti penting merek PTMA di tengah persaingan antar Perguruan Tinggi. Brand Activation menjadi alat yang dapat memberikan manfaat bagi PTMA sebagai Perguruan Tinggi dan PTMA sebagai merek secara bersamaan dengan memberikan eksposur dan pengalaman kepada pelanggan.

Penelitian ini juga menunjukkan bagaimana media sosial hadir sebagai solusi bagi PTMA dalam menjalankan aktivitas brand activation di masa Pandemi COVID-19. Loyalitas merek PTMA yang tinggi dapat dicapai melalui kombinasi pemanfaatan sosial media dan kegiatan sosial yang melibatkan partisipasi seluruh stakeholders.

Di masa Pandemi COVID-19, keterikatan kognitif, afektif, dan perilaku perlu ditingkatkan agar loyalitas terhadap merk dapat dicapai. Karena pada dasarnya, efek sosial terkait manusia lebih kuat daripada efek yang terkait dengan suatu merek (Singh \& Ang, 2020). Aktivitas-aktivitas brand activation PTMA lebih didorong untuk meningkatkan relasi sosial antar aktor yang ada di dalamnya. Karena hubungan khalayak dengan suatu suatu brand menunjukkan pengaruh positif dan signifikan terhadap loyalitas merek (Kumar, 2020b).

\section{SIMPULAN}

Strategi brand activation PTMA di masa pandemi diwujudkan melalui berbagai macam program yang berbasis bantuan dan sukarelawan. Aktivitas brand activation PTMA yang terdapat di Daerah Istimewa Yogyakarta ini juga tetap merujuk pada kebijakan penanganan COVID-19 Pimpinan Pusat Muhammadiyah dan Aisyiyah dengan instruksi utama mengamalkan caturdharma perguruan tinggi untuk masyarakat yang terdampak. Hasilnya 
adalah munculnya berbagai keunikan pada masing-masing PTMA yang terlihat dari slogan yang dipakai, kampus berwawasan kesehatan, kampus muda mendunia, dan kampus Islam berkemajuan.

Kegiatan brand activation di masa pandemi ini menimbulkan perubahan pola perilaku pemasaran yang menggunakan media sosial. Ketiga kampus yang diteliti telah menunjukkan bagaimana konvergensi media pemasaran yang mereka lakukan dapat membuat model promosi menjadi lebih menarik dan efisien.

Saran penelitian adalah kegiatan brand activation perlu lebih dielaborasi pada pengamalan caturdharma sehingga semakin memperkuat brand PTMA sebagai satu entitas kolektif di masyarakat. PTMA juga perlu membuat satu konsep aktivitas brand activation yang dilaksanakan secara bersama. Hal tersebut dapat semakin memperkuat relasi dan kerja sama antar sesama PTMA dalam menghadapi persaingan baik dengan PT negeri maupun swasta.

\section{DAFTAR PUSTAKA}

Ali, M. (2016). Membedah tujuan pendidikan Muhammadiyah. PROFETIKA, Jurnal Studi Islam, 17(1), 43-56. http://journals. ums.ac.id/index.php/profetika/article/ viewFile/2099/1489

Ayu Retno Widyastuti, D., Beny Pramudyanto, A., \& Noor Prima Astuti, R. A. V. (2018). Dinamika dalam membangun merek kolektif pada usaha mikro, kecil, dan menengah. Komunikator, 10(2). https:// doi.org/10.18196/jkm.101013

Bacow, L. (2020, March 10). COVID-19 moving classes online, other updates. [Community Message]. Harvard University. https://www.harvard.edu/ COVID-19moving-classes-online-other-updates

Brodie, R. J., Hollebeek, L. D., Jurić, B., \& Ilić, A. (2011). Customer engagement: conceptual domain, fundamental propositions, and implications for research. Journal of Service Research, 14(3), 252-271. https:// doi.org/10.1177/1094670511411703

Bungin, B. (2007). Analisis data penelitian kualitatif. Depok: Raja Grafindo Persada.

Demmers, J., Weltevreden, J. W. J., \& van Dolen, W. M. (2020). Consumer engagement with brand posts on social media in consecutive stages of the customer journey. International Journal of Electronic Commerce, 24(1), 53-77. https://doi.org/10.1080/10864415. 2019.1683701

Gendron, M. (2017). From public realtions to brand activation: integrating today's communications tools to move business forward. Global Business and Organizational Excellence, 36(3), 6-13. https://doi.org/10.1002/j

Guarner, J. (2020). Three emerging coronaviruses in two decades: the story of sars, mers, and now COVID-19. American Journal of Clinical Pathology, 153(4), 420-421. https://doi.org/10.1093/ajcp/ aqaa029

Herdiansyah, H. (2010). Metodologi penelitian kualitatif untuk ilmu-ilmu sosial. Jakarta: Salemba Humanika.

Jinan, M. (2015). Muhammadiyah studies: transformasi kajian tentang gerakan islam di Indonesia. Analisa Journal of Social 
Science and Religion, 22(2), 269-280. https://doi.org/10.18784/analisa.v22i2.96

Kozinets, R., Cova, B., \& Shankar, A. (2007). Consumer tribes: theory, practice, and prospects. London, Elsevier/ButterworthHeinemann, doi, 10, 9780080549743.

Kumar, V. (2020a). Building customer-brand relationships through customer brand engagement. Journal of Promotion Management, 26(7), 986-1012. https://doi. org/10.1080/10496491.2020.1746466

Kumar, V. (2020b). Building customer-brand relationships through customer brand engagement. Journal of Promotion Management, 26(7), 986-1012. https://doi. org/10.1080/10496491.2020.1746466

Leckie, C., Nyadzayo, M. W., \& Johnson, L. W. (2016). Antecedents of consumer brand engagement and brand loyalty. Journal of Marketing Management, 32(5-6), 558-578. https://doi.org/10.1080/026725 $7 X .2015 .1131735$

Liembawati, Y., Dharmayanti, D., Si, M., Karina, R., Pemasaran, P. M., Petra, U. K., \& Siwalankerto, J. (2014). Analisa pengaruh brand activation terhadap pembentukan brand community pada PT ISM Bogasari flour mills. Jurnal Manajemen Pemasaran Petra, 2(1), 1-15.

Lubis, M., \& Ganiem, L. M. (2017). Pencapaian brand corporate melalui brand activation pendekatan experiential marketing (studi kasus laboratorium klinik). Jurnal Komunikasi, 9(1), 1. https://doi. org/10.24912/jk.v9i1.457

Mason, A. N., Narcum, J., \& Mason, K. (2021). Social media marketing gains importance after COVID-19. Cogent Business and Management, 8(1). https://doi.org/10.1080 /23311975.2020.1870797

Moelong, Lexy J. (2007). Metode penelitian kualiatif. Bandung: Remaja Rosdakarya. Morel, P., Preisler, P., \& Nyström, A. (2002). Brand activation. Starsky Insight, 5-8.

Murphy, M. P. A. (2020). COVID-19 and emergency eLearning: consequences of the securitization of higher education for post-pandemic pedagogy. Contemporary Security Policy, 41(3), 492-505. https:// doi.org/10.1080/13523260.2020.1761749

Putri, N. E., Hakim, N., \& Yamin, M. (2016). Ecologicall footprint and biocapacity analysis for flooding prevention in South Sumatera. Jurnal Mimbar, 32(1), 58-64.

Ratriyana, I. N. (2019). Ekuitas merek lokal Jogja di mata generasi millenials. Jurnal ASPIKOM, 3(6), 1163. https://doi. org/10.24329/aspikom.v3i6.410

Rodrigues, C. L \& Maria, C. L. S. (2019). The importance of employees' engagement on the organizational success. Journal of Promotion Management, 25(3), 328-336. https://doi.org/10.1080/10496491.2019.15 57811

Singarimbun, M., \& Effendi, S. (2011). Metodologi penelitian survei (revisi). Depok: LP3ES Indonesia.

Singh, C., \& Ang, L. (2020). Persuasive effects in social media: the case of envy. International Journal of Advertising, O(0), 1-25. https://doi.org/10.1080/02650487.20 20.1830686

Sutrisna, E. (2015). Muhammadiyah dan gerakan kesehatan berkemajuan. Tajdida, 13(1), 9-16.

Weeden, K. A., \& Cornwell, B. (2020). Status and vocal accommodation in small groups. Sociological Science, 7, 222-241. https:// doi.org/10.15195/V7.A9

Yin, R. K. (2006). Studi kasus: desain dan metode (terjemahan). Depok: Grafindo Persada. 
Yusuf, F. (2016). Optimalisasi program branding dan aktivasi merek di era digital. Jurnal Komunikasi, 7(1), 7-13. http://ejournal. bsi.ac.id/ejurnal/index.php/jkom/article/ view/2169/1531 